\title{
Relationship among Short and Long Term of Hypoinsulinemia-Hyperglycemia, Dermatophytosis, and Immunobiology of Mononuclear Phagocytes
}

\author{
Thais F. C. Fraga-Silva, ${ }^{1,2}$ Camila M. Marchetti, ${ }^{1}$ Luiza A. N. Mimura, \\ Gisele A. Locachevic, ${ }^{3}$ Márjorie A. Golim, ${ }^{4}$ James Venturini, ${ }^{1}$ and Maria S. P. Arruda ${ }^{1}$ \\ ${ }^{1}$ Department of Biological Sciences, School of Sciences, Universidade Estadual Paulista (UNESP), 17033-360 Bauru, SP, Brazil \\ ${ }^{2}$ Department of Microbiology and Immunology, Institute of Biosciences of Botucatu, Universidade Estadual Paulista (UNESP), \\ 18618-970 Botucatu, SP, Brazil \\ ${ }^{3}$ Department of Clinical, Toxicological and Bromatological Analysis, School of Pharmaceutical Sciences of Ribeirão Preto, \\ University of São Paulo (USP), 14040-903 Ribeirão Preto, SP, Brazil \\ ${ }^{4}$ Botucatu Blood Center, Universidade Estadual Paulista (UNESP), 18618-970 Botucatu, SP, Brazil
}

Correspondence should be addressed to Maria S. P. Arruda; lipe@fc.unesp.br

Received 29 April 2015; Revised 27 June 2015; Accepted 26 July 2015

Academic Editor: Ana P. M. Serazani

Copyright (C) 2015 Thais F. C. Fraga-Silva et al. This is an open access article distributed under the Creative Commons Attribution License, which permits unrestricted use, distribution, and reproduction in any medium, provided the original work is properly cited.

\begin{abstract}
Dermatophytes are fungi responsible for causing superficial infections. In patients with diabetes mellitus (DM), dermatophytosis is usually more severe and recurrent. In the present study, we aimed to investigate the influence of short and long term hypoinsulinemia-hyperglycemia $(\mathrm{HH})$ during experimental infection by Trichophyton mentagrophytes as well as alterations in the mononuclear phagocytes. Our results showed two distinct profiles of fungal outcome and immune response. Short term $\mathrm{HH}$ induced a discrete impaired proinflammatory response by peritoneal adherent cells (PAC) and a delayed fungal clearance. Moreover, long term HH mice showed low and persistent fungal load and a marked reduction in the production of TNF- $\alpha$ by PAC. Furthermore, while the inoculation of TM in non-HH mice triggered high influx of $\mathrm{Grl}^{+}$monocytes into the peripheral blood, long term HH mice showed low percentage of these cells. Thus, our results demonstrate that the time of exposure of HH interferes with the TM infection outcome as well as the immunobiology of mononuclear phagocytes, including fresh monocyte recruitment from bone marrow and PAC activity.
\end{abstract}

\section{Introduction}

Dermatophytes are fungi responsible for superficial infections in skin, hair, and nails [1]. Dermatophytosis affects approximately $20-25 \%$ of the world's population [2-4] and Trichophyton rubrum and Trichophyton mentagrophytes (TM) are the most common causative agents $[4,5]$. Patients with diabetes mellitus (DM) are particularly susceptible to this fungal infection [6-8]. While fingernail due to TM is observed in $30.8 \%$ of type I DM, nondiabetic patients exhibit prevalence of $4.54 \%$ [9].

Several physiologic and metabolic disorders, such as peripheral vascular disease, peripheral neuropathy, poor glycemic control, obesity, and hypertriglyceridemia, are associated with high rates of infection in DM patients [10]. Simultaneously, DM triggers several changes in the immune response, including an unbalanced macrophage activity [11]. Although monocytes/macrophages from onset type I DM as well as from experimental diabetic murine models showed a proinflammatory profile, characterized by intense production of hydrogen peroxide $\left(\mathrm{H}_{2} \mathrm{O}_{2}\right)$ and release of TNF- $\alpha[12$, 13], this profile is not able to prevent mycotic infections in DM patients. The interaction of T. rubrum conidia with nonactivated resident peritoneal macrophages leads to downregulation of costimulatory molecules expression, such as CD80 and CD54, and phagocytosis but induces production 
of TNF- $\alpha$ and IL-10 [14]. Thus, the balance between intense proinflammatory response observed in DM and the modulation of macrophage activity triggered by dermatophytes remains to be clarified.

Recently, at least two subsets of human and murine monocytes have been recognized according to their functions under inflammatory and steady-state conditions [15]; these subsets can be identified by the expression of the surface molecules CD14 and CD16 in humans (classical $\mathrm{CD}_{14}{ }^{+} \mathrm{CD}_{16}{ }^{-}$and nonclassical $\mathrm{CD} 14^{+} \mathrm{CD} 16^{+}$monocytes) [16] and Ly6C/Ly6G (Gr1) in mice (resident CD115 ${ }^{+} \mathrm{Grl}^{-}$and inflammatory $\mathrm{CD}_{115^{+}} \mathrm{Grl}^{+}$monocytes) $[17,18]$. The murine $\mathrm{CD}_{115}{ }^{+} \mathrm{Grl}^{+}$monocyte subset expresses high levels of the adhesion molecule E-selectin (CD62L) and CC-chemokine receptor 2 (CCR2) [18]. According to Landsman et al. [19], this monocyte subset migrates between the blood and the bone marrow and is only found in other locations when recruited as a result of inflammation. $\mathrm{CD}_{115}{ }^{+} \mathrm{Grl}^{-}$monocytes differ by their absent/low Grl receptor expression and higher fractalkine receptor (CX3CR1) expression [17]; this monocyte subset exhibits blood vessel patrolling behavior and may serve as precursor to alternatively activated macrophages during tissue repair and resident macrophage/dendritic cells (DCs) turnover [20]. A recent report has shown that type I DM patients exhibit an expansion of the pool of nonclassical $\mathrm{CD}_{14}{ }^{+} \mathrm{CD} 16^{+}$monocytes [21]; however, the consequence of this expansion and their potential use as a biomarker of inflammation must be further elucidated.

In a previous study we observed that hyperglycemichypoinsulinemic $(\mathrm{HH})$ mice infected with $T$. mentagrophytes showed a delay in the fungal clearance after 14 days after infection [22]. This result was associated with decreased counts of peripheral blood $\mathrm{CD} 4^{+} \mathrm{T}$ cells [22]. In a present study, we hypothesized that during the early infection progress, when $\mathrm{HH}$ and normal mice exhibit similar fungal burden, alterations in the innate immune response could be associated with the delay in the outcome of dermatophyte-infected $\mathrm{HH}$ mice. Thus, we aimed to evaluate the peritoneal adherent cells activity as well as the distribution of peripheral blood monocyte subsets in $\mathrm{HH}$ mice infected with T. mentagrophytes. Furthermore, we investigated the effect of time of $\mathrm{HH}$ exposition in these mice.

\section{Methods}

2.1. Mice. Two-month-old male, weight-matched, Swiss mice purchased from CEMIB/UNICAMP (Campinas, São Paulo, Brazil) were maintained at the Animal House of the Laboratório de Imunopatologia Experimental, LIPE (UNESP, Bauru, SP, Brazil). The mice were housed in groups of three to five and were provided with food and water ad libitum. The experimental protocol was performed in accordance with the ethical principles for animal research adopted by the National Council for the Control of Animal Experimentation (CONCEA). This study was approved by the Ethical Committee of School of Sciences (UNESP, Bauru, SP, Brazil).

2.2. Fungi. The Trichophyton mentagrophytes (TM) strain (2118/99-ILSL) was isolated from a human lesion and obtained from the fungal collection of the Lauro de Souza Lima Institute, Bauru, São Paulo State, Brazil, and was maintained by frequent subculture on a Mycosel agar (Difco Laboratories, USA) slant at $25^{\circ} \mathrm{C}$ in our laboratory.

2.3. Induction of HH Condition Using Alloxan Administration. Alloxan administration to laboratory animals selectively destroys insulin-producing pancreatic $\beta$-cells $[22,23]$ without promoting pancreatitis $[24,25]$. Mice were intravenously administered alloxan (Sigma Chemical Co., St. Louis, MO) in a single dose of $60 \mathrm{mg} \mathrm{kg}^{-1}$ of body weight injected into the caudal vein. Hyperglycemia was confirmed $48 \mathrm{~h}$ later using Accu-Chek Advantage II blood glucose test strips (Roche, Mannheim, Germany). Only mice showing blood glucose levels $>200 \mathrm{mg} \mathrm{dL}^{-1}$ were considered as having $\mathrm{HH}$ and included in the experiment. The glucose levels during the experiment were typically $400-600 \mathrm{mg} \mathrm{dL}^{-1}$ in $\mathrm{HH}$ mice. In the present study, the success rate of alloxan-induced $\mathrm{HH}$ was approximately $80-90 \%$. Control mice (TM and CTL) presented serum glucose levels ranging from 90 to $180 \mathrm{mg} \mathrm{dL}^{-1}$.

2.4. Fungal Inoculum. The strain was cultured on Mycosel agar slants for 10 days at $25^{\circ} \mathrm{C}$. The fungi were washed carefully with a sterile saline solution. The fungal suspension was then mixed twice for $10 \mathrm{~s}$ on a vortex mixer and decanted for $5 \mathrm{~min}$. The supernatants were collected and washed twice [26]. Fungal viability was determined by cotton blue staining, and the concentrations were adjusted to $5 \times 10^{8}$ viable TM conidia per $\mathrm{mL}$. The mice were subcutaneously injected in the footpad, with $0.04 \mathrm{~mL}$ of TM inoculum (HHTM and TM groups). Noninfected groups ( $\mathrm{HH}$ and CTL groups) were treated identically with a sterile saline solution.

2.5. Experimental Designs. The study was performed using two distinct experimental designs according to the time of $\mathrm{HH}$ exposure: 7 (short term) and 21 (long term) days after $\mathrm{HH}$ induction (Figure 1). Each experiment included four subgroups as follows: (1) HHTM group, composed of HH mice inoculated with TM; (2) HH group, composed of $\mathrm{HH}$ mice and noninfected mice; (3) TM group, composed of non- $\mathrm{HH}$ mice and inoculated with TM; (4) control group, composed of non-HH mice and uninfected mice. All mice were submitted to the same procedures and sterile saline solution was used as placebo control. The mice were euthanized at 1,2, and 7 days after fungal challenge, that is, on 8,9 , and 14 (short term) days and 22, 23, and 28 (long term) days after $\mathrm{HH}$ installation. The study was performed at least in two independent experiments and 5 or 6 mice were enrolled in each subgroup per time point.

2.6. Collection of the Biological Material. Mice were euthanized by $\mathrm{CO}_{2}$ inhalation, and fresh peripheral blood was collected by cervical decapitation into a tube containing ethylenediaminetetraacetic acid (EDTA) as an anticoagulant. Tissue was then dissected from the footpad, popliteal lymph nodes, liver, spleen, and kidneys and submitted to microbiological analyses. 


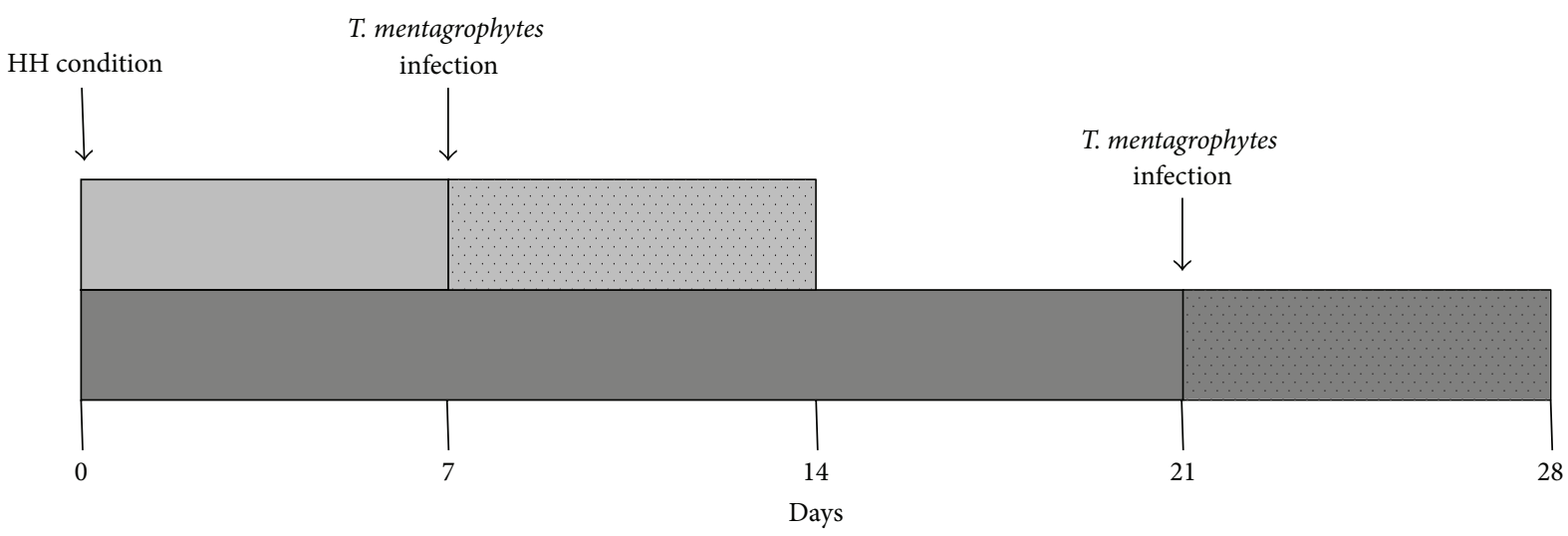

(a)

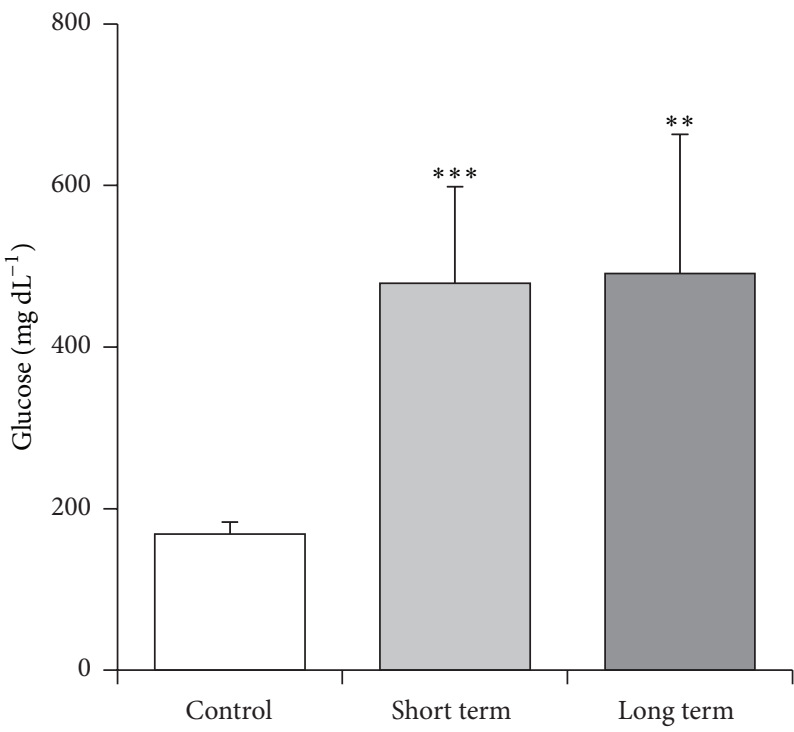

(b)

Figure 1: Experimental design. Mice were intravenously inoculated with alloxan $\left(60 \mathrm{mg} \mathrm{kg}^{-1}\right)$ into the caudal vein. Hyperglycemia was confirmed after $48 \mathrm{~h}$ by blood glucose levels $>200 \mathrm{mg} \mathrm{dL}^{-1}$. (a) Mice that were exposed to $\mathrm{HH}$ condition for 7 days constituted the $\mathrm{HH}$ group (short term) and those for 21 days constituted the HH group (long term). Mice from HH groups (short and long term) were infected with $2 \times 10^{7}$ T. mentagrophytes microconidia into footpad. (b) Glucose levels ( $\mathrm{mg} \mathrm{dL}^{-1}$ ) after 7 days (short term) and 21 days (long term) of $\mathrm{HH}$ installation. The results are expressed as mean $\pm \mathrm{SD}(n=6-12 /$ group $)$. Unpaired $t$-test, $p<0.05$. ${ }^{*} p<0.05$ and ${ }^{* *} p<0.01$ indicate statistical differences among $\mathrm{HH}$ group versus the control group (uninfected/HH-free mice).

2.7. Colony-Forming Unit (CFU) Determination. Fragments of the collected organs were weighed and homogenized in $1 \mathrm{~mL}$ of PBS, and $0.1 \mathrm{~mL}$ of the homogenate was cultured on $15 \times 90 \mathrm{~mm}$ Mycosel agar plates at $25^{\circ} \mathrm{C}$ for 14 days. Each sample was assessed in duplicate. Total colonies were counted, and the results were expressed as the CFU number $\left(\log _{10}\right)$ of TM per gram of tissue.

2.8. Peritoneal Adherent Cell Culture. After euthanasia, mouse abdominal skin was removed, and peritoneal cell suspensions were obtained by washing the peritoneal cavity with $10 \mathrm{~mL}$ of sterile ice-cold phosphate-buffered saline (PBS) in $\mathrm{pH} 7,4$. The suspension was then centrifuged and the cells were resuspended in $1.0 \mathrm{~mL}$ of RPMI-1640 (Nutricell, Campinas, SP, Brazil) supplemented with $10 \%$ heat-inactivated fetal calf serum (Gibco BRL, Grand Island, NY, USA), penicillin (100 $\left.\mathrm{IU} \mathrm{mL}^{-1}\right)$, and streptomycin $\left(100 \mathrm{mg} \mathrm{mL}^{-1}\right)$ (Gibco). The cell concentration was adjusted to $2.0 \times 10^{6}$ mononuclear phagocytes $\mathrm{mL}^{-1}$ as judged by the uptake of $0.02 \%$ neutral red. The peritoneal cells were placed in 96well flat-bottomed microtiter plates (Costar, Cambridge, MA, USA) and incubated for 2 hours at $37^{\circ} \mathrm{C}$ and $5 \% \mathrm{CO}_{2}$ in a humidified chamber to allow peritoneal cells to adhere and spread. Nonadherent cells were removed by washing the wells 3 times with RPMI-1640, and the remaining adherent cells (>95\% mononuclear phagocytes as assessed by morphological examination) were used for experiments. The peritoneal adherent cells (PAC) were cultured at $37^{\circ} \mathrm{C}$ and $5 \% \mathrm{CO}_{2}$ in supplemented RPMI-1640. After 24 hours, the cell-free supernatants were harvested and stored at $-80^{\circ} \mathrm{C}$ pending cytokine analysis. 
2.9. Measurement of Hydrogen Peroxide Release $\left(\mathrm{H}_{2} \mathrm{O}_{2}\right)$. PAC $\left(2 \times 10^{6}\right.$ cells $\left.\mathrm{mL}^{-1}\right)$ obtained as described before were maintained in RPMI-1640 culture medium at $37^{\circ} \mathrm{C}$ and $5 \%$ $\mathrm{CO}_{2}$ for $24 \mathrm{~h}$. At the end of the cell culture period, the supernatant was removed and macrophages were incubated with phenol red solution (dextrose (Sigma), phenol red (Sigma), and horseradish peroxidase type II (Sigma)) and plated at $37^{\circ} \mathrm{C}$ in $5 \% \mathrm{CO}_{2}$ for $1 \mathrm{~h}$ according to the methods of Russo et al. [27]. The reaction was stopped with the addition of $1 \mathrm{~N} \mathrm{NaOH}$ and the $\mathrm{H}_{2} \mathrm{O}_{2}$ concentration was determined using a chemiluminescence microreader (ELx 800; BioTek Instruments Inc., Winooski, VE, USA).

2.10. Quantification of Nitric Oxide (NO) Production. To determine NO levels, the production of nitrite (a stable end product of NO) was measured in the cell-free supernatants of PAC cultured according to the methods of Green et al. [28]. Briefly, $0.1 \mathrm{~mL}$ of cell-free supernatant was incubated with an equal volume of Griess reagent containing 1\% sulfanilamide (Synth, Diadema, SP, Brazil), 0.1\% naphthalene diamine dihydrochloride (Sigma), and $2.5 \% \mathrm{H}_{3} \mathrm{PO}_{4}$, at room temperature for $10 \mathrm{~min}$, and the nitrite accumulation was quantified using an chemiluminescence microreader (ELx 800; BioTek Instruments Inc., Winooski, VE, USA). The concentration of nitrite was determined using sodium nitrite (Sigma) diluted in RPMI-1640 medium as a standard.

2.11. Cytokine Analyses. The levels of TNF- $\alpha$ and IL-10 were measured in the cell-free supernatants using a cytokine DuoSet Kit (R\&D Systems, Minneapolis, MI, USA), according to the manufacturer's instructions. Each sample was analyzed in duplicate.

2.12. Determination of Peripheral Blood Monocyte Subsets. Blood monocyte subsets, obtained as described above, were analyzed for differences in the profile expression of surface molecules by flow cytometry using a fluorescence-activated cell sorter (FACS) according to Breslin et al. [29]. The following monoclonal antibodies were purchased from BioLegend (San Diego, CA, USA): Alexa Fluor 488-conjugated rat IgG2b anti-mouse Ly-6G/Ly-6C (Gr1), clone RB6-8C5; phycoerythrin- (PE-) conjugated rat IgG2a anti-mouse CD115 (CSF-1R), clone AFS98; allophycocyanin- (APC-) conjugated rat IgG2b anti-mouse CD45, clone 30-F11; and rat IgG2a and rat IgG2b isotype controls. Flow cytometry was performed using a FACSCalibur (BD), and the data were analyzed using FlowJo software (Tree Star).

2.13. Statistical Analysis. To test for the normality of data, results were analyzed by Shapiro-Wilk's test. Comparisons between two samples were made by unpaired $t$-test and more than three samples were made by one-way ANOVA followed by Tukey's test for parametric variables and by Kruskal-Wallis followed by Dunn's test for nonparametric variables. The data were analyzed using the software GraphPad Prism 5 (San Diego, CA, USA) and values of $p<0.05$ were considered statistically significant.

\section{Results}

3.1. Long Term HH Mice Infected with TM Exhibit Persistent Viable Fungi. As observed in Figure 2, the viable fungi were recovered from all evaluated organs, including the footpad, popliteal lymph nodes, and spleen. After 7 days after infection (p.i.) all groups exhibited lower fungal load compared to day 1 in footpad samples (Figure 2(a)). The popliteal lymph nodes (Figure 2(b)) and spleen (Figure 2(c)) fungal burden decreased after 2 days p.i. in non-HH TM infected mice (TM group) and decreased after 7 days p.i. in TM and short term HHTM groups, compared with fungal burden at day 1 p.i. The fungal load was lower in popliteal lymph nodes samples of short and long term $\mathrm{HH}$ infected groups compared to TM group (Figure $2(\mathrm{~b})$ ) at day 1 p.i.

3.2. T. mentagrophytes Clearance Is Associated with Early Release of Fresh Blood Inflammatory Monocytes and Regulated Macrophage Activity. As expected, 1 day after fungal inoculation, we observed in the TM group an increased percentage of $\mathrm{CD} 15^{+} \mathrm{Grl}^{+}$monocytes in the peripheral blood (Figures 3(a) and 3(c)). At 2 days p.i., when the fungal load started to decrease, the levels returned to normal. At this time point (2 days p.i.) the peritoneal adherent cells of the TM group showed high levels of TNF- $\alpha$, IL-10, and $\mathrm{H}_{2} \mathrm{O}_{2}$ (Figures 4 (a)$4(\mathrm{c})$ ). On day 7, the levels of TNF- $\alpha$ and $\mathrm{H}_{2} \mathrm{O}_{2}$ remained higher than the control group (Figures 4(a)-4(c)).

3.3. Long Term of HH Exposure Increases the Numbers of Total Blood Monocytes and $\mathrm{GrI}^{+}$Monocytes and Decreases the Production of $\mathrm{H}_{2} \mathrm{O}_{2}$ and TNF- $\alpha$ by Peritoneal Adherent Cells. Next, we evaluated the influence of $\mathrm{HH}$ condition per se, that is, in noninfected mice. Although there was no difference in glucose levels between short and long term $\mathrm{HH}$ mice (Figure 1), we observed increased percentage of $\mathrm{Grl}^{+}$ monocytes on day 28 (Figure 3(b)). The HH-induced mice showed high production of $\mathrm{H}_{2} \mathrm{O}_{2}$, reaching a peak at the 14 th day; afterwards, the levels started to decrease, and from the 23rd day the production was lower than the control group (Figure $4(\mathrm{~d})$ ). The levels of TNF- $\alpha$ remained unaltered in the short term of $\mathrm{HH}$ condition; from day 22 (long term), the levels were lower than the control group (Figure 4(e)). The IL-10 levels are the same in all experimental times points in the short term of $\mathrm{HH}$ condition; from day 22 (long term), the levels were higher than the control group (Figure 4(f)).

3.4. T. mentagrophytes Challenge in HH Long Term Reduces Percentage of Peripheral Blood Gr1 ${ }^{+}$Monocytes and Decreases the Production of TNF- $\alpha$ by Peritoneal Adherent Cells. As for distribution of peripheral blood monocyte subsets, we observed that mice of HHTM long term group showed lower percentage of $\mathrm{Grl}^{+}$monocytes on day 1 p.i. than TM group (Figure 3(e)). We also observed an increased production of $\mathrm{H}_{2} \mathrm{O}_{2}$ at 1 day p.i. by PAC only in the long term HHTM group compared to the TM and long term HHTM groups (Figure 5(a)). However, at 2 days p.i. both short term and long term HHTM groups showed a lower $\mathrm{H}_{2} \mathrm{O}_{2}$ production in comparison to TM group. At 7 days long term HHTM 


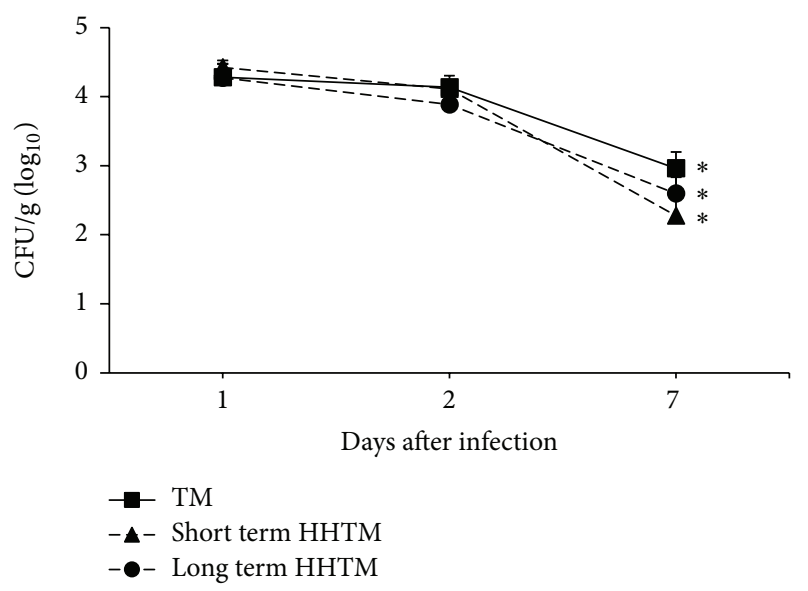

(a) Footpad

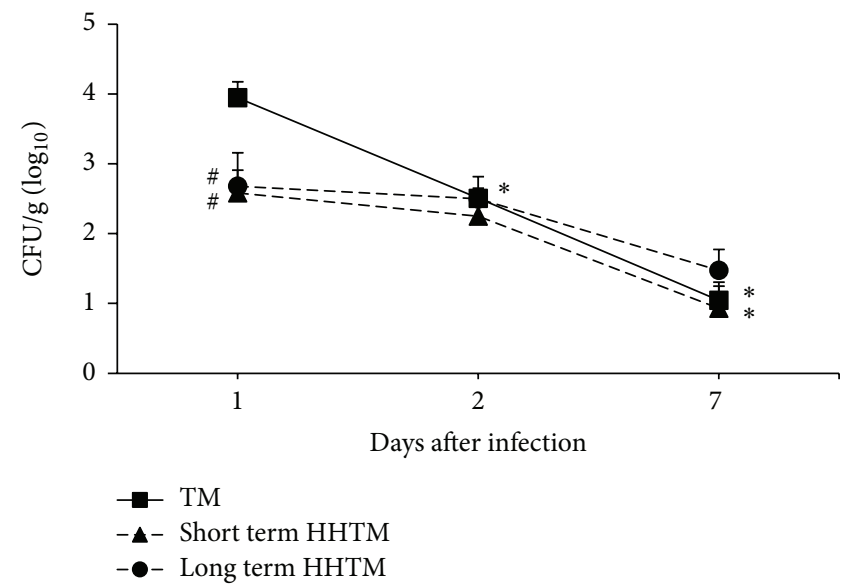

(b) Lymph nodes

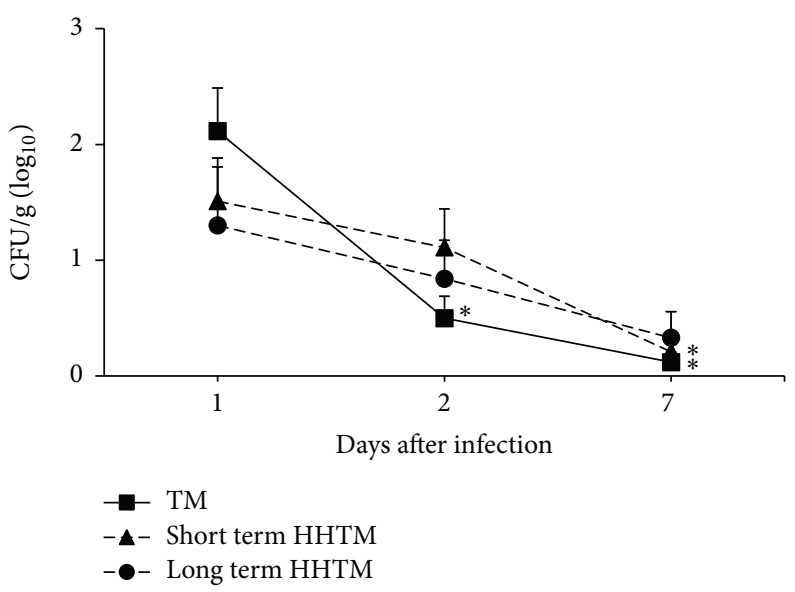

(c) Spleen

Figure 2: Microbiological evaluation. Swiss mice were infected with T. mentagrophytes and fungal load was evaluated 1, 2, and 7 days after infection in the footpads (a), popliteal lymph nodes (b), and spleen (c). The results are expressed as mean \pm SD ( $n=6-12 /$ group) of the CFU $\left(\log _{10}\right)$ per gram of tissue. Unpaired $t$-test, $p<0.05 .{ }^{*}$ Statistical difference to day 1 and ${ }^{*}$ statistical difference between TM and HHTM groups in the same time point.

group showed a lower $\mathrm{H}_{2} \mathrm{O}_{2}$ production in comparison to TM and long term HHTM groups (Figure 5(a)). The long term HHTM group showed a TNF- $\alpha$ decrease in comparison to TM group in all periods analyzed (Figure 5(b)). Additionally, at 2 days p.i. the long term HHTM group showed a TNF$\alpha$ decrease in comparison to short term HHTM group (Figure 5(b)). Our results demonstrate an IL-10 increase at 1 day p.i. in short term HHTM group compared to the TM and long term HHTM groups (Figure 5(c)). The long term HHTM group showed an IL-10 decrease at 1 and 2 days p.i. compared to short term HHTM group and showed an IL-10 decrease at 2 days p.i. compared to TM group (Figure 5(c)). No differences were observed at 7 days p.i. among the groups.

\section{Discussion}

In a previous report, we have demonstrated that $\mathrm{HH}$ alloxan-induced mice exhibit a delay in the T. mentagrophytes clearance [22] that mimics one important aspect of the severity of dermatophytosis in DM patients. However, chronic dermatophytosis, subclinical infection, and recurrence episodes, also observed in DM patients, as well as immune-related mechanisms involved in these processes remain to be elucidated. Here, we extend our findings and aim to evaluate the initials immune-related mechanisms involved in T. mentagrophytes (TM) infection associated with different time of $\mathrm{HH}$ exposure. For this, we focused on evaluating the peritoneal adherent cells (PAC) activity and the distribution of peripheral blood monocyte subsets in $\mathrm{HH}$ mice inoculated with TM during short and long term state of $\mathrm{HH}$ condition.

Interestedly, soon after fungal inoculation (day 1), we observed that the fungal load in the popliteal lymph nodes was lower in the HHTM groups. According to Moriguchi et al. [30], the high blood levels of glucose present in $\mathrm{HH}$ mice lead to increased local lymphatic drainage and impaired dextran particles retention in the lymph nodes. Thus, the loss of the particle retention ability of the lymph nodes could explain the lower fungal load in HHTM mice. Moreover, the TM group showed downfungal burden at 2 days p.i. in internal organs while in short term HHTM the fungal burden decreased at 7 days and in the long term HHTM the fungal 

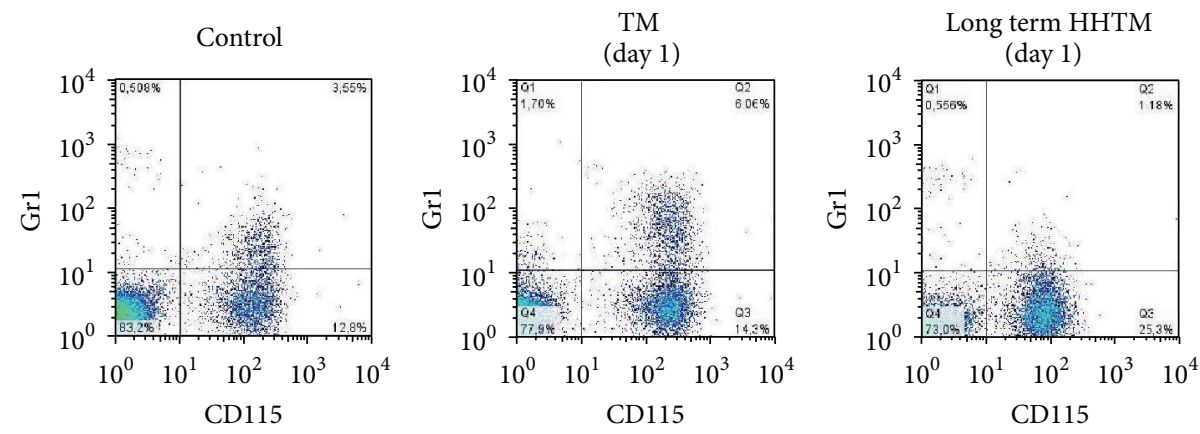

(a)
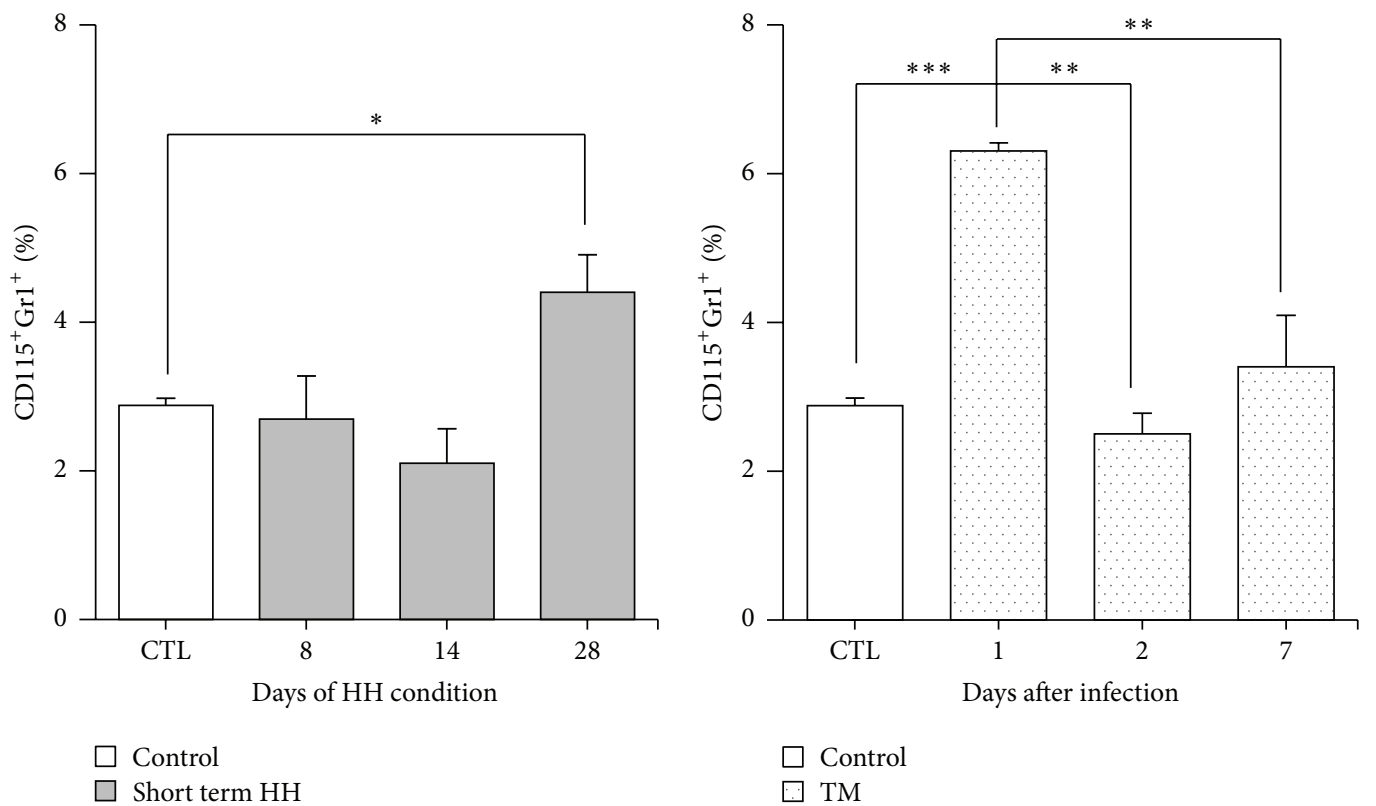

(b) HH group

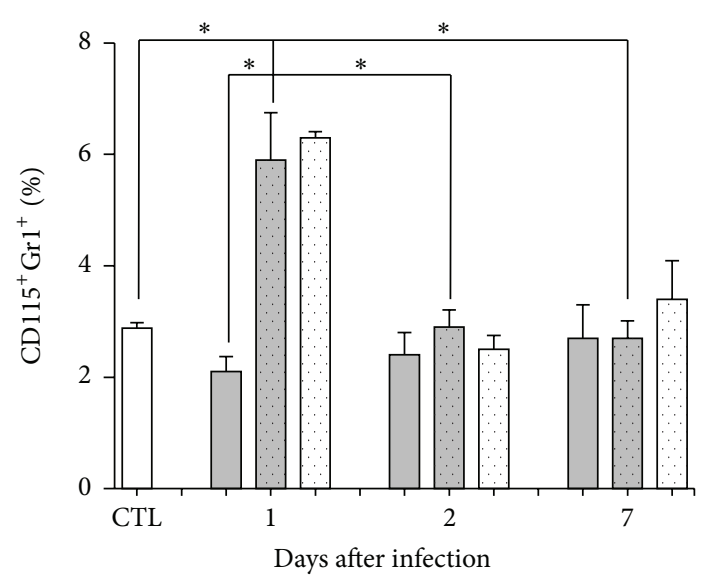

(c) TM group

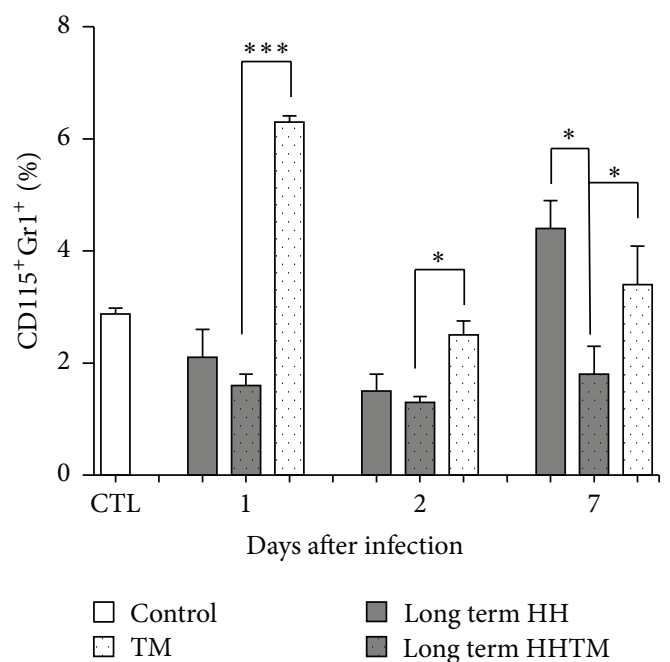

(d) $\operatorname{HHTM}$ (short term)

(e) HHTM (long term)

FIGURE 3: The distribution of peripheral blood monocyte subsets in TM-infected mice and noninfected HH mice. (a) Representative flow cytometry dot plot of data acquisition showing CD115 and Grl surface expression on peripheral blood cells. The numbers in the dot plots represent the percentages of each cell population within the square. (b) The distribution of inflammatory $\mathrm{CD}_{115^{+} \mathrm{Grl}}{ }^{+}$monocytes in the $\mathrm{HH}$ group. Peripheral blood cells were analyzed from 8 to 28 days after $\mathrm{HH}$ induction. (c) The distribution of inflammatory $\mathrm{CD}_{115}{ }^{+} \mathrm{Gr} 1^{+}$ monocytes in the TM group. Peripheral blood cells were analyzed at 1,2, and 7 days after fungal challenge. (d) The distribution of inflammatory

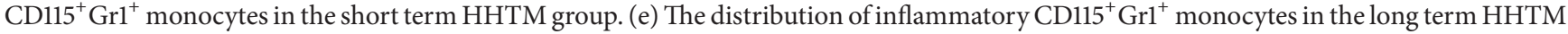
group. Data are expressed as the mean \pm SEM of percentages and are representative of two independent experiments $(n=6$ mice/group). Multiple comparisons of means were performed using ANOVA with the Tukey post hoc test $\left({ }^{*} p \leq 0.05\right)$. 


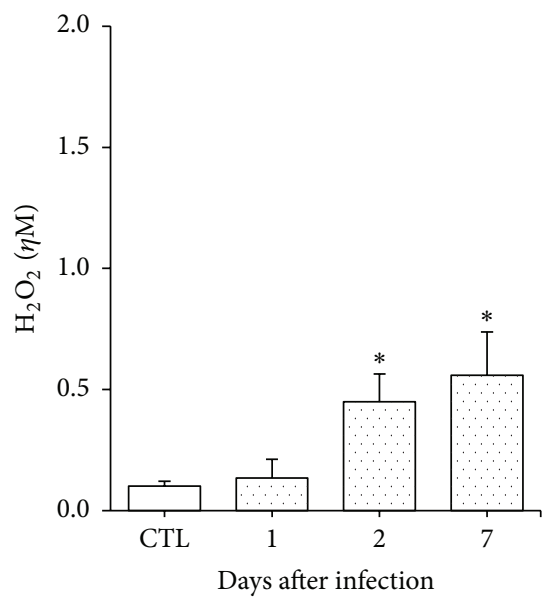

(a) TM group

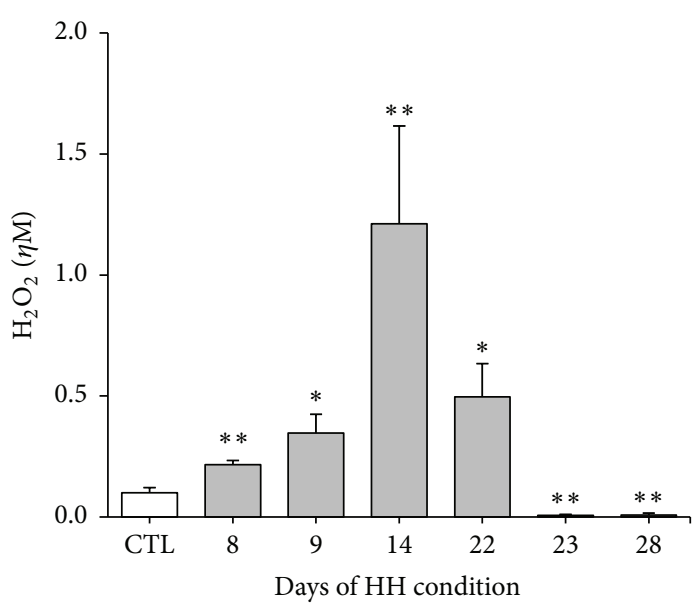

(d) HH group

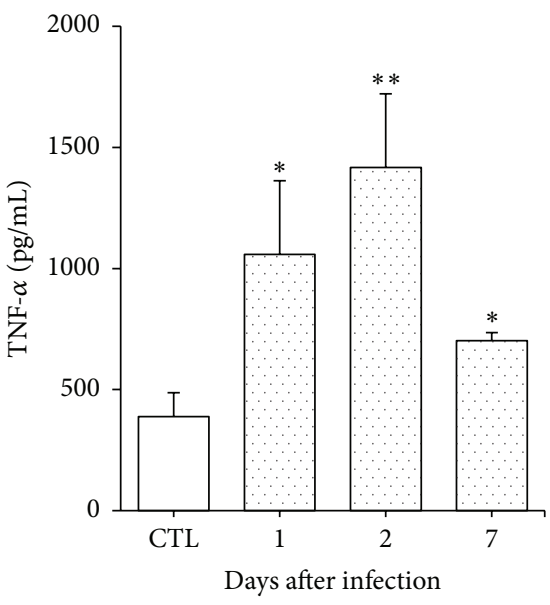

(b) TM group

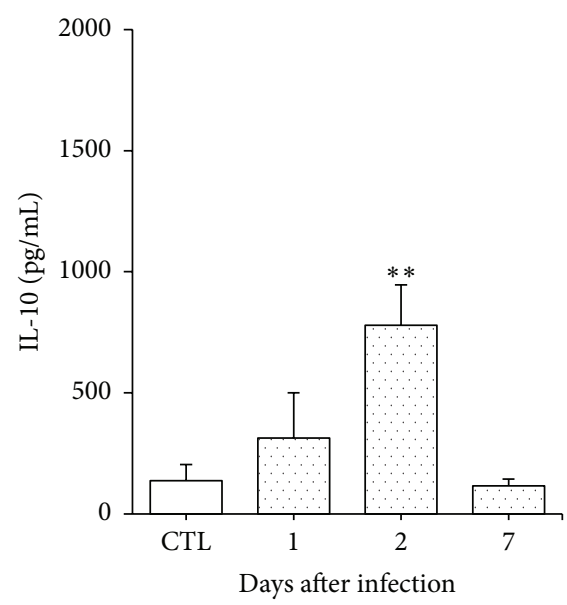

(c) TM group

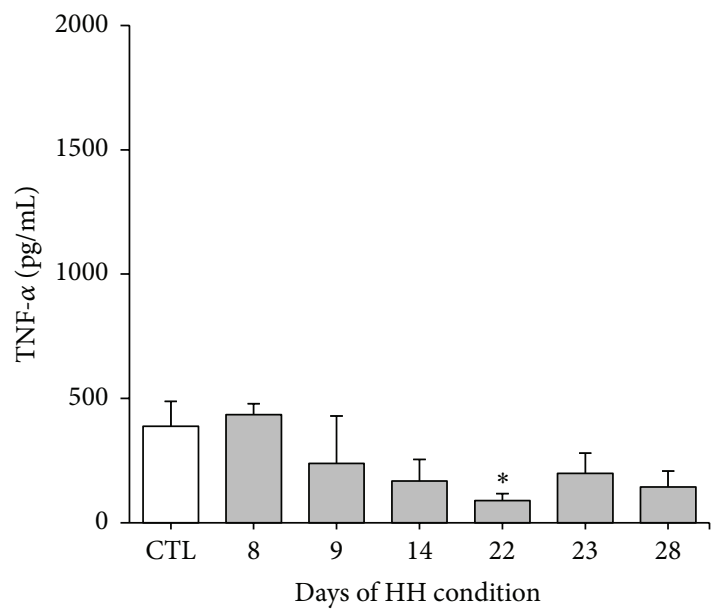

(e) $\mathrm{HH}$ group

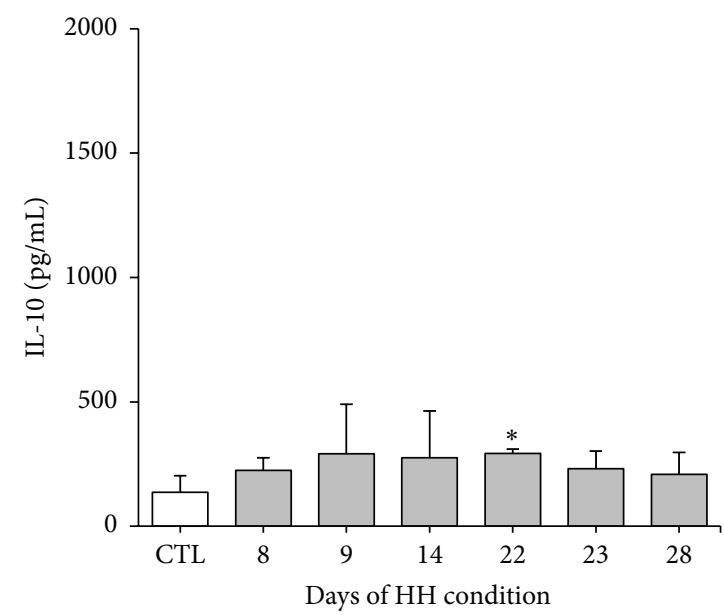

(f) $\mathrm{HH}$ group

FIGURE 4: Kinects of hydrogen peroxide $\left(\mathrm{H}_{2} \mathrm{O}_{2}\right)$, tumor necrosis factor- (TNF-) $\alpha$, and interleukin- (IL-) 10 production by PAC from mice infected with T. mentagrophytes and HH mice. The results are expressed as mean $\pm \operatorname{SEM}\left(n=5\right.$-6/group). Unpaired $t$-test, $p<0.05$. ${ }^{*} p<0.05$ and ${ }^{* *} p<0.01$ indicate statistical differences between each experimental time point versus the control group (uninfected/HH-free mice). 


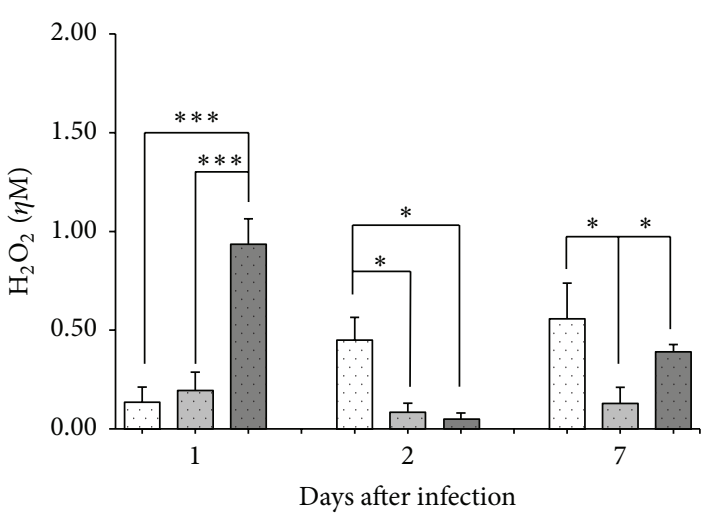

$\square$ TM
Short term HHTM

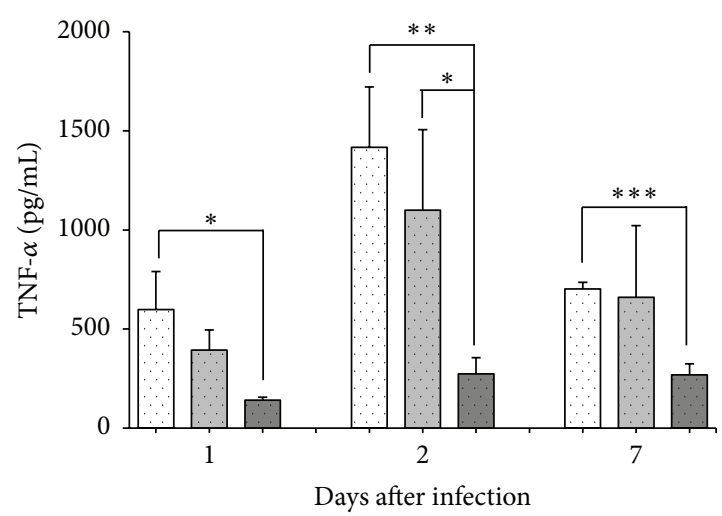

$\square \mathrm{TM}$

Short term HHTM

$\square$ Long term HHTM

(a)

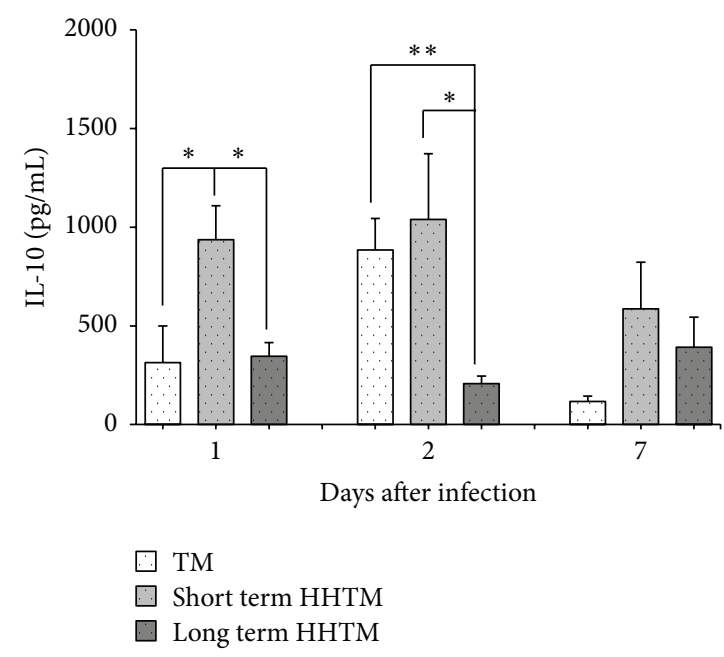

(c)

FIgURE 5: The hydrogen peroxide $\left(\mathrm{H}_{2} \mathrm{O}_{2}\right)$ (a), tumor necrosis factor- (TNF-) $\alpha$ (b), and interleukin- (IL-) 10 (c) production. Peritoneal adherent cells were analyzed at 1,2 , and 7 days after fungal challenge. Data are expressed as the mean \pm SEM and are representative of two independent experiments ( $n=5-6$ mice/group). The comparison between TM and HHTM groups was performed using unpaired $t$-test $\left({ }^{*} p \leq 0.05,{ }^{* *} p \leq 0.01\right.$, and $\left.{ }^{* * *} p \leq 0.001\right)$.

burden remains. Our findings demonstrated that, in the long term $\mathrm{HH}$ mice, TM infection is more discrete but persistent. These results indicate a possible defect in the innate immunity of DM patients and reinforce the hypothesis that internal organs could act as a reservoir for dermatophytes [31].

With regard to monocytes subsets, a large number of newly induced $\mathrm{Grl}^{+}$cells are released from the bone marrow into the blood stream and these cells enter the infected tissue and participate in the initial phase of the inflammatory response in short time, thereafter differentiating into proinflammatory macrophages and TNF-producing DCs [32, 33]. The high percentage of this monocyte observed on day 1 after fungal challenge underlines that also T. mentagrophytes are able to trigger this response. Even in the presence of fungi on day 2 , the percentage of peripheral blood $\mathrm{Grl}^{+}$ monocytes decreased to the baseline percentage. Uninfected $\mathrm{HH}$ mice exhibited high percentages of peripheral blood total monocytes and $\mathrm{Grl}^{+}$monocytes only at 28 days after $\mathrm{HH}$ induction. A recent study demonstrated that streptozotocin(STZ-) induced diabetes mice develop several changes in the bone marrow after 12 months, including increased numbers of inflammatory CCR2 ${ }^{+}$monocytes that can "home" to the target tissues of chronic diabetic complications, such as the retina and the kidney [34]. Although our results are in agreement with those of Hazra et al. [34], the experimental model of alloxan-induced $\mathrm{HH}$ goes beyond because it permits the evaluation of two $\mathrm{HH}$-related alterations: short term $\mathrm{HH}$ (HH per se) and chronic disturbances evoked by long term $\mathrm{HH}$. Thus, the results observed at 28 days after $\mathrm{HH}$ induction in mice with alloxan-induced $\mathrm{HH}$ appear to be more related to the severe damage caused by chronic $\mathrm{HH}$ disturbances.

Our results showed that fungal infections processes in the early phase of $\mathrm{HH}$ (per se) did not alter the distribution of peripheral blood monocyte subsets. On the other hand, 
the long term HHTM mice showed lower percentage of $\mathrm{Grl}^{+}$monocytes rather than the expected increase. This phenomenon could be related to at least three mechanisms: (1) impaired CCR2-mediated recruitment from the bone marrow; (2) increased migration from the blood stream to the bone marrow or to the sites of infection/inflammation;

(3) fast differentiation to $\mathrm{Grl}^{-}$monocytes.

It has been described that hyperglycemia induces intracellular ROS directly, mainly by AGE/RAGE interactions [3537]. Our results exhibited the same profile; $\mathrm{HH}$ mice showed an increased production of $\mathrm{H}_{2} \mathrm{O}_{2}$ until day 22 after $\mathrm{HH}$ condition; however, in the HHTM groups the production of $\mathrm{H}_{2} \mathrm{O}_{2}$ decreased on the second day p.i. Considering that $\mathrm{H}_{2} \mathrm{O}_{2}$ is a potential fungicidal against T. mentagrophytes [38] and T. rubrum [39], the lower production of $\mathrm{H}_{2} \mathrm{O}_{2}$ probably contributed to fungal delay and/or persistence. Furthermore, we observed that long term $\mathrm{HH}$ leads to a reduced production of TNF- $\alpha$ even during fungal challenge. Similarly, peritoneal macrophages with "M2-like" phenotype have also been recently identified in animals with prolonged DM [11, 40]. Besides a proinflammatory response, a concomitant and regulated immune response is a crucial step to eliminate pathogens. Antigens of T. rubrum trigger IL-10 and TNF$\alpha$ production by peritoneal macrophages [14]. Also in vivo experiments showed simultaneous release of these cytokines that was associated with protective response [26]. In the present study, mice from long term HHTM group showed low levels of IL-10 and TNF- $\alpha$, suggesting that short and long term exposition to $\mathrm{HH}$ condition result in different degrees of unbalanced PAC activity.

Briefly, our study showed that (1) short and long term $\mathrm{HH}$ interfered with the dynamic of fungal dissemination to the internal organs; (2) long term $\mathrm{HH}$ affected the response of mononuclear cells by increasing the percentages of total monocytes and $\mathrm{Grl}^{+}$monocytes and the production of $\mathrm{H}_{2} \mathrm{O}_{2}$ but decreasing TNF- $\alpha$ production by peritoneal adherent cells; (3) long term HHTM mice showed a lower percentage of peripheral blood $\mathrm{Grl}^{+}$monocytes and decreased TNF$\alpha$ production by peritoneal adherent cells. Our findings go beyond the fungal-host relationship in a $\mathrm{HH}$ milieu and bring new immunological descriptions in dermatophytosis and in the alloxan-induced $\mathrm{HH}$ mice.

\section{Disclosure}

The funder had no role in the study design, data collection and analysis, decision to publish the paper, or preparation of the paper.

\section{Conflict of Interests}

The authors declare that they have no conflict of interests.

\section{Authors' Contribution}

Thais F. C. Fraga-Silva and Camila M. Marchetti contributed equally to this paper.

\section{Acknowledgments}

This work was supported by the Sao Paulo Research Foundation (FAPESP, Grants nos. 2009/50654-1, 2009/50818-4, and 2009/52911-1). The authors also thank Valéria Alves da Silva for providing helpful assistance with the flow cytometry assays.

\section{References}

[1] B. L. Hainer, "Dermatophyte infections," The American Family Physician, vol. 67, no. 1, pp. 101-108, 2003.

[2] P. R. Murray, K. S. Rosenthal, G. Kobayashi, and M. A. Pfaller, Microbiology Medical, Mosby, St. Louis, Mo, USA, 1997.

[3] B. Havlickova, V. A. Czaika, and M. Friedrich, "Epidemiological trends in skin mycoses worldwide," Mycoses, vol. 51, supplement 4, pp. 2-15, 2008.

[4] R. Kaur, B. Kashyap, and P. Bhalla, "Onychomycosisepidemiology, diagnosis and management," Indian Journal of Medical Microbiology, vol. 26, no. 2, pp. 108-116, 2008.

[5] Ş. Gürcan, M. Tikveşli, M. Eskiocak, H. Kiliç, and M. Otkun, "Investigation of the agents and risk factors of dermatophytosis: a hospital-based study," Mikrobiyoloji Bulteni, vol. 42, no. 1, pp. 95-102, 2008.

[6] L. M. A. J. Muller, K. J. Gorter, E. Hak et al., "Increased risk of common infections in patients with type 1 and type 2 diabetes mellitus," Clinical Infectious Diseases, vol. 41, no. 3, pp. 281-288, 2005.

[7] S. Gupta, J. Koirala, R. Khardori, and N. Khardori, "Infections in diabetes mellitus and hyperglycemia," Infectious Disease Clinics of North America, vol. 21, no. 3, pp. 617-638, 2007.

[8] H. Parada, C. Veríssimo, J. Brandão et al., "Dermatomycosis in lower limbs of diabetic patients followed by podiatry consultation," Revista Iberoamericana de Micología, vol. 30, no. 2, pp. 103-108, 2013.

[9] A. B. Macura, T. Gasińska, B. Pawlik, and A. Obłoza, "Nail susceptibility to fungal infection in patients with type 1 and 2 diabetes under long term poor glycaemia control," Przegla, lekarski, vol. 64, no. 6, pp. 406-409, 2007.

[10] S. Cathcart, W. Cantrell, and B. Elewski, "Onychomycosis and diabetes," Journal of the European Academy of Dermatology and Venereology, vol. 23, no. 10, pp. 1119-1122, 2009.

[11] C. Sun, L. Sun, H. Ma et al., “The phenotype and functional alterations of macrophages in mice with hyperglycemia for long term," The Journal of Cellular Physiology, vol. 227, no. 4, pp. 1670-1679, 2012.

[12] G. A. Limb, A. H. Chignell, W. Green, F. LeRoy, and D. C. Dumonde, "Distribution of TNF $\alpha$ and its reactive vascular adhesion molecules in fibrovascular membranes of proliferative diabetic retinopathy," British Journal of Ophthalmology, vol. 80, no. 2, pp. 168-173, 1996.

[13] G. K. Kolluru, S. C. Bir, and C. G. Kevil, "Endothelial dysfunction and diabetes: effects on angiogenesis, vascular remodeling, and wound healing," International Journal of Vascular Medicine, vol. 2012, Article ID 918267, 30 pages, 2012.

[14] M. R. M. Campos, M. Russo, E. Gomes, and S. R. Almeida, "Stimulation, inhibition and death of macrophages infected with Trichophyton rubrum," Microbes and Infection, vol. 8, no. 2, pp. 372-379, 2006.

[15] F. Tacke and G. J. Randolph, "Migratory fate and differentiation of blood monocyte subsets," Immunobiology, vol. 211, no. 6-8, pp. 609-618, 2006. 
[16] F. Geissmann, C. Auffray, R. Palframan et al., "Blood monocytes: distinct subsets, how they relate to dendritic cells, and their possible roles in the regulation of T-cell responses," Immunology and Cell Biology, vol. 86, no. 5, pp. 398-408, 2008.

[17] B. Passlick, D. Flieger, and H. W. Loms Ziegler-Heitbrock, "Identification and characterization of a novel monocyte subpopulation in human peripheral blood," Blood, vol. 74, no. 7, pp. 2527-2534, 1989.

[18] F. Geissmann, S. Jung, and D. R. Littman, "Blood monocytes consist of two principal subsets with distinct migratory properties," Immunity, vol. 19, no. 1, pp. 71-82, 2003.

[19] L. Landsman, C. Varol, and S. Jung, "Distinct differentiation potential of blood monocyte subsets in the lung," The Journal of Immunology, vol. 178, no. 4, pp. 2000-2007, 2007.

[20] M. Nahrendorf, F. K. Swirski, E. Aikawa et al., "The healing myocardium sequentially mobilizes two monocyte subsets with divergent and complementary functions," The Journal of Experimental Medicine, vol. 204, no. 12, pp. 3037-3047, 2007.

[21] J. Myśliwska, M. Smardzewski, N. Marek-Trzonkowska, M. Myśliwiec, and K. Raczyńska, "Expansion of $\mathrm{CD}_{14}{ }^{+} \mathrm{CD} 16^{+}$ monocytes producing TNF- $\alpha$ in complication-free diabetes type 1 juvenile onset patients," Cytokine, vol. 60, no. 1, pp. 309317, 2012.

[22] J. Venturini, M. A. Golim, A. M. Alvares, G. A. Locachevic, O. S. Arruda, and M. S. Arruda, "Morphofunctional evaluation of thymus in hyperglycemic-hypoinsulinemic mice during dermatophytic infection," FEMS Immunology and Medical Microbiology, vol. 62, no. 1, pp. 32-40, 2011.

[23] S. Lenzen, "The mechanisms of alloxan- and streptozotocininduced diabetes," Diabetologia, vol. 51, no. 2, pp. 216-226, 2008.

[24] A. A. Rossini, A. A. Like, W. L. Chick, M. C. Appel, and G. F. Cahill Jr., "Studies of streptozotocin induced insulitis and diabetes," Proceedings of the National Academy of Sciences of the United States of America, vol. 74, no. 6, pp. 2485-2489, 1977.

[25] E. A. Abd elaziz, "Pathological and biochemical studies on the effect of Trigonella foenum-Graecum and Lupinus termis in Alloxan induced diabetic rats," World Applied Sciences Journal, vol. 12, no. 10, pp. 1839-1850, 2011.

[26] J. Venturini, A. M. Álvares, M. R. de Camargo et al., "Dermatophyte-host relationship of a murine model of experimental invasive dermatophytosis," Microbes and Infection, vol. 14, no. 13, pp. 1144-1151, 2012.

[27] M. Russo, H. C. Teixeira, M. C. Marcondes, and J. A. Barbuto, "Superoxide-independent hydrogen peroxide release by activated macrophages," Brazilian Journal of Medical and Biological Research, vol. 22, no. 10, pp. 1271-1273, 1989.

[28] L. C. Green, D. A. Wagner, J. Glogowski, P. L. Skipper, J. S. Wishnok, and S. R. Tannenbaum, "Analysis of nitrate, nitrite, and $[15 \mathrm{~N}]$ nitrate in biological fluids," Analytical Biochemistry, vol. 126, no. 1, pp. 131-138, 1982.

[29] W. L. Breslin, K. Strohacker, K. C. Carpenter, D. L. Haviland, and B. K. McFarlin, "Mouse blood monocytes: standardizing their identification and analysis using CD115," Journal of Immunological Methods, vol. 390, no. 1-2, pp. 1-8, 2013.

[30] P. Moriguchi, P. Sannomiya, P. F. Lara, R. M. Oliveira-Filho, K. V. Greco, and L. S. Sudo-Hayashi, "Lymphatic system changes in diabetes mellitus: role of insulin and hyperglycemia," Diabetes/Metabolism Research and Reviews, vol. 21, no. 2, pp. 150-157, 2005.

[31] J. Van Cutsem and P. A. J. Janssen, "Experimental systemic dermatophytosis," Journal of Investigative Dermatology, vol. 83, no. 1, pp. 26-31, 1984.
[32] T. Bosschaerts, M. Guilliams, B. Stijlemans et al., “Tip-DC development during parasitic infection is regulated by IL-10 and requires CCL2/CCR2, IFN- $\gamma$ and MyD88 signaling," PLoS Pathogens, vol. 6, no. 8, Article ID e1001045, 2010.

[33] F. Geissmann, M. G. Manz, S. Jung, M. H. Sieweke, M. Merad, and K. Ley, "Development of monocytes, macrophages, and dendritic cells," Science, vol. 327, no. 5966, pp. 656-661, 2010.

[34] S. Hazra, Y. P. R. Jarajapu, V. Stepps et al., "Long-term type 1 diabetes influences haematopoietic stem cells by reducing vascular repair potential and increasing inflammatory monocyte generation in a murine model," Diabetologia, vol. 56, no. 3, pp. 644-653, 2013.

[35] H. Sano, T. Higashi, K. Matsumoto et al., "Insulin enhances macrophage scavenger receptor-mediated endocytic uptake of advanced glycation end products," The Journal of Biological Chemistry, vol. 273, no. 15, pp. 8630-8637, 1998.

[36] F. Giacco and M. Brownlee, "Oxidative stress and diabetic complications," Circulation Research, vol. 107, no. 9, pp. 10581070, 2010.

[37] V. Scivittaro, M. B. Ganz, and M. F. Weiss, "AGEs induce oxidative stress and activate protein kinase C- $\beta$ (II) in neonatal mesangial cells," The American Journal of Physiology-Renal Physiology, vol. 278, no. 4, pp. F676-F683, 2000.

[38] K. A. Moriello and H. Hondzo, "Efficacy of disinfectants containing accelerated hydrogen peroxide against conidial arthrospores and isolated infective spores of Microsporum canis and Trichophyton sp.", Veterinary Dermatology, vol. 25, no. 3, pp. e191-e48, 2014.

[39] K. G. MacCarthy and M. V. Dahl, "Inhibition of growth of Trichophyton rubrum by the myeloperoxidase-hydrogen peroxidechloride system," Journal of Investigative Dermatology, vol. 92, no. 4, pp. 639-641, 1989.

[40] H.-F. Liu, H.-J. Zhang, Q.-X. Hu et al., "Altered polarization, morphology, and impaired innate immunity germane to resident peritoneal macrophages in mice with long-term type 2 diabetes," Journal of Biomedicine and Biotechnology, vol. 2012, Article ID 867023, 9 pages, 2012. 


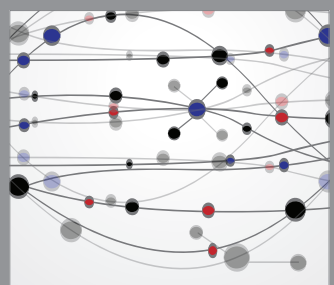

The Scientific World Journal
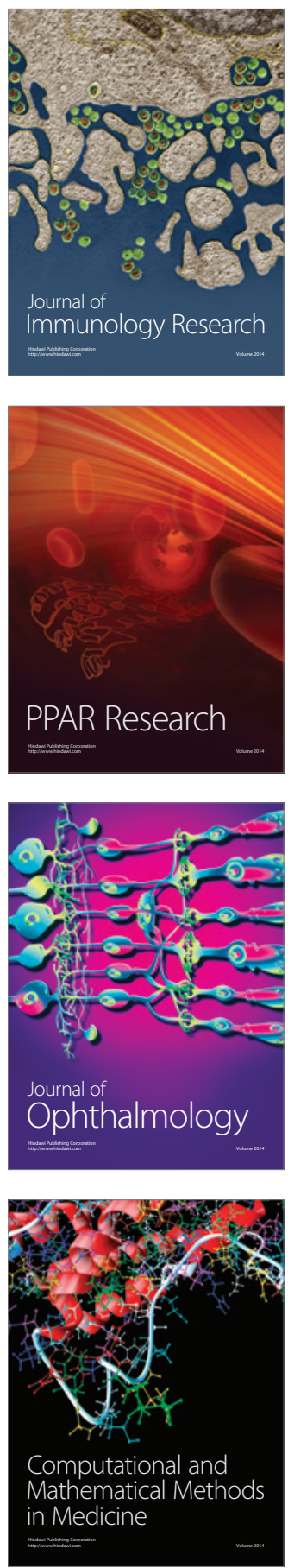

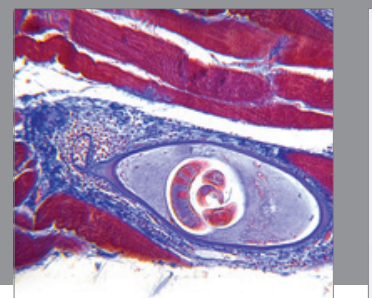

Gastroenterology

Research and Practice
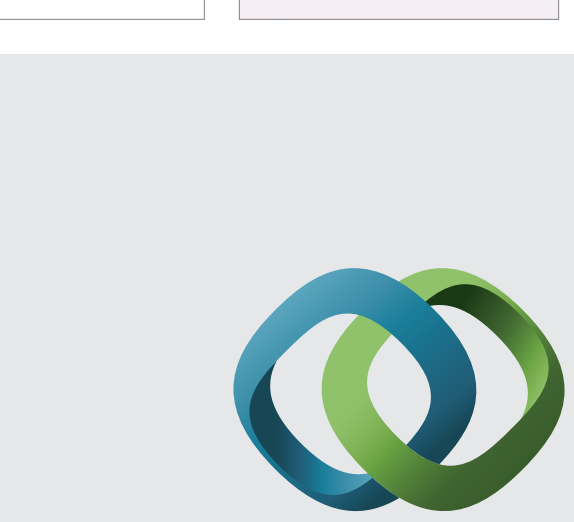

\section{Hindawi}

Submit your manuscripts at

http://www.hindawi.com
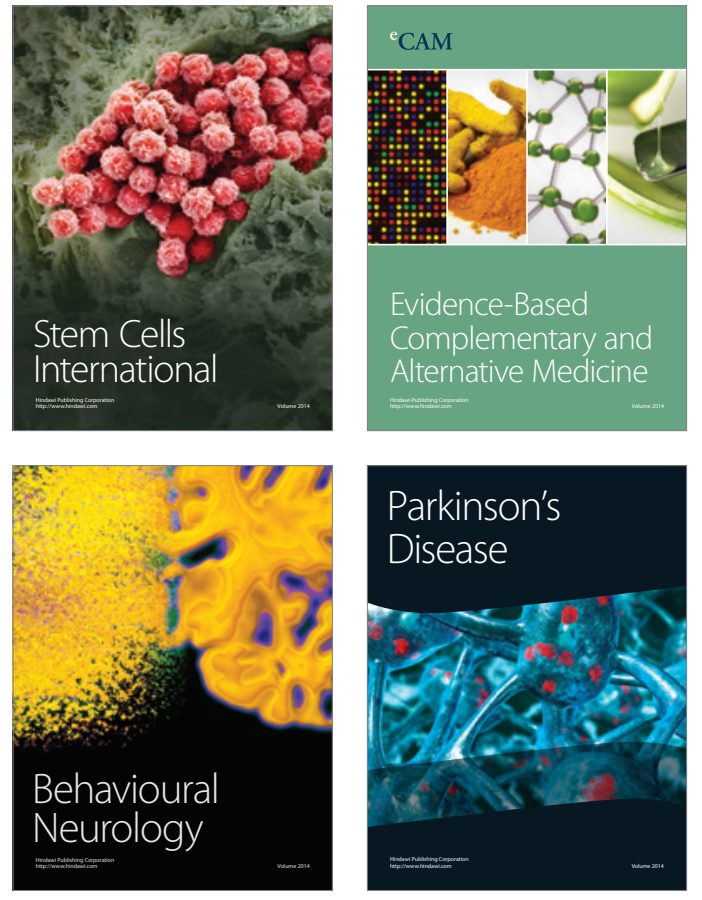
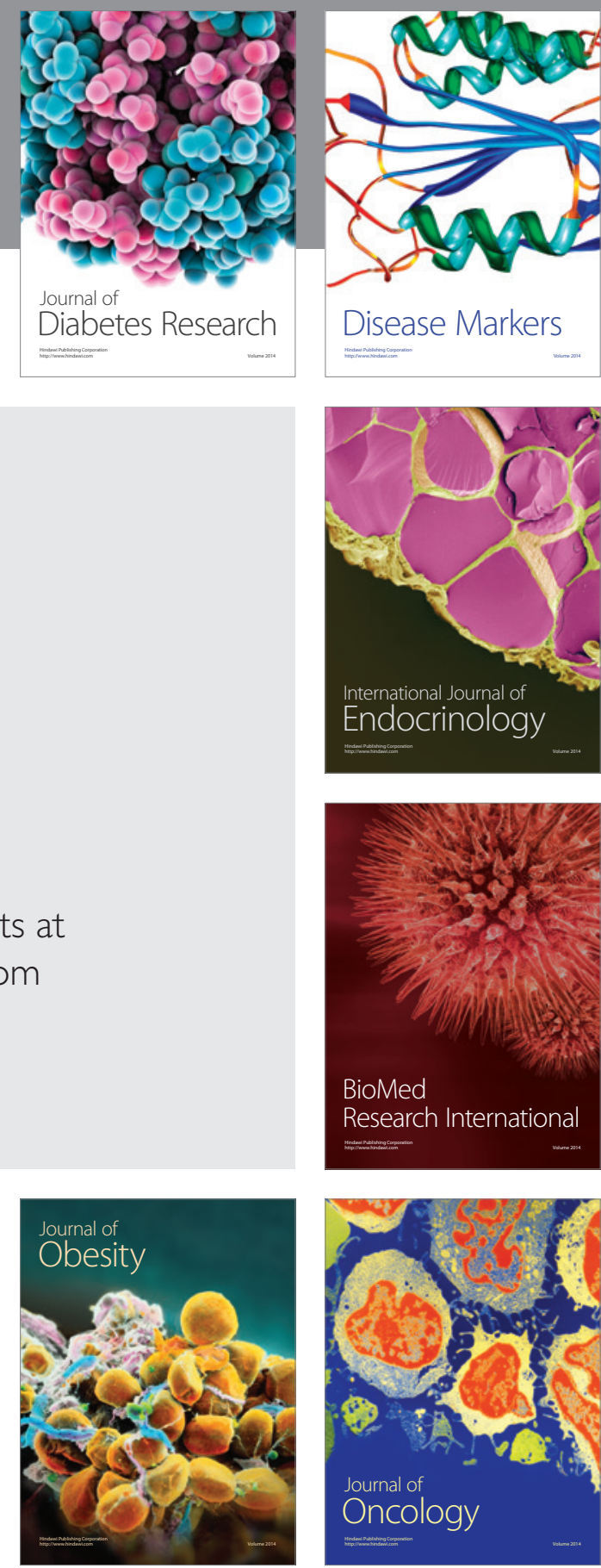

Disease Markers
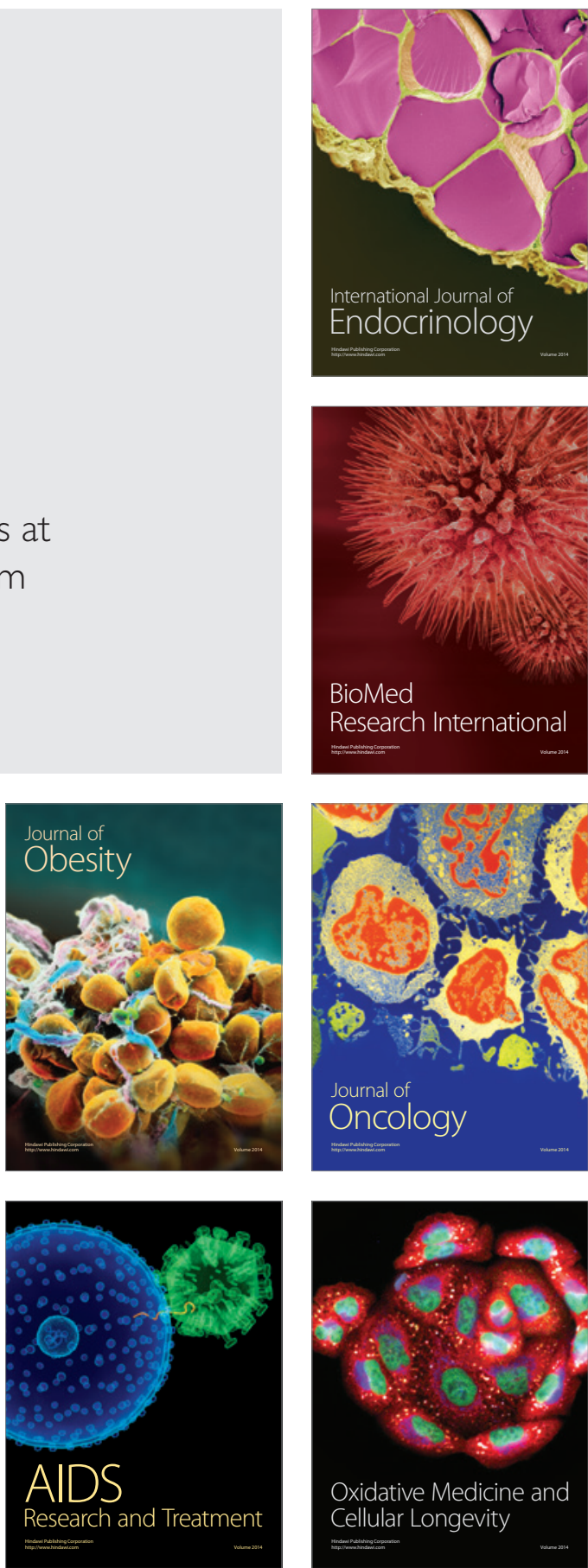